\title{
Experimental determination of the heat transfer coefficient for the optimal design of the cooling system of a PEM fuel cell placed inside the fuselage of an UAV
}

Jorge Barroso ${ }^{1}$, Jordi Renau ${ }^{2}$, Antonio Lozano ${ }^{1}$, José Miralles ${ }^{2}$, Jesús Martín ${ }^{1}$, Fernando Sánchez ${ }^{2}$, Félix Barreras ${ }^{1, *}$

1 LIFTEC, CSIC - Universidad de Zaragoza. Maria de Luna 10, 50018 - Zaragoza. SPAIN

2 UCH CEU. Universidad CEU Cardenal Herrera. C/ San Bartolomé, 55, 461150 - Alfara del Patriarca, Valencia. SPAIN

\begin{abstract}
The objective of this research is to calculate the heat transfer coefficients needed for the further design of the optimal cooling system of a high-temperature polymer electrolyte membrane fuel cell (HT-PEMFC) stack that will be incorporated to the powerplant of a light unmanned aerial vehicle (UAV) capable of reaching an altitude of $10,000 \mathrm{~m}$. Experiments are performed in two rectangular tunnels, for three different form factors, in experimental conditions as close as possible to the actual ones in the HT-PEMFC stack. For the calculations, all the relevant thermal processes are considered. Different parameters are measured, such as air mass flow rate, inlet and outlet air temperatures, and wall temperatures for bipolar plates and endplates. Different numerical models are fitted revealing the influence of the diverse relevant non-dimensional groups on the Nusselt number. Heat transfer coefficients calculated for the air cooling flow vary from 8 to $44 \mathrm{~W} \mathrm{~m}^{-2} \mathrm{~K}^{-1}$. Results obtained at sea level are extrapolated for a flight ceiling of $10 \mathrm{~km}$. The flow section is optimized as a function of the power required to cool the stack down to the temperature recommended by the membrane-electrode assembly (MEA) manufacturer using a numerical code specifically developed for this purpose.
\end{abstract}

Keywords: Heat transfer coefficient, PEM fuel cell, Hydrogen, Heat transfer management, UAV

\footnotetext{
*Corresponding author. E-Mail: felix@litec.csic.es
} 


\section{Nomenclature}

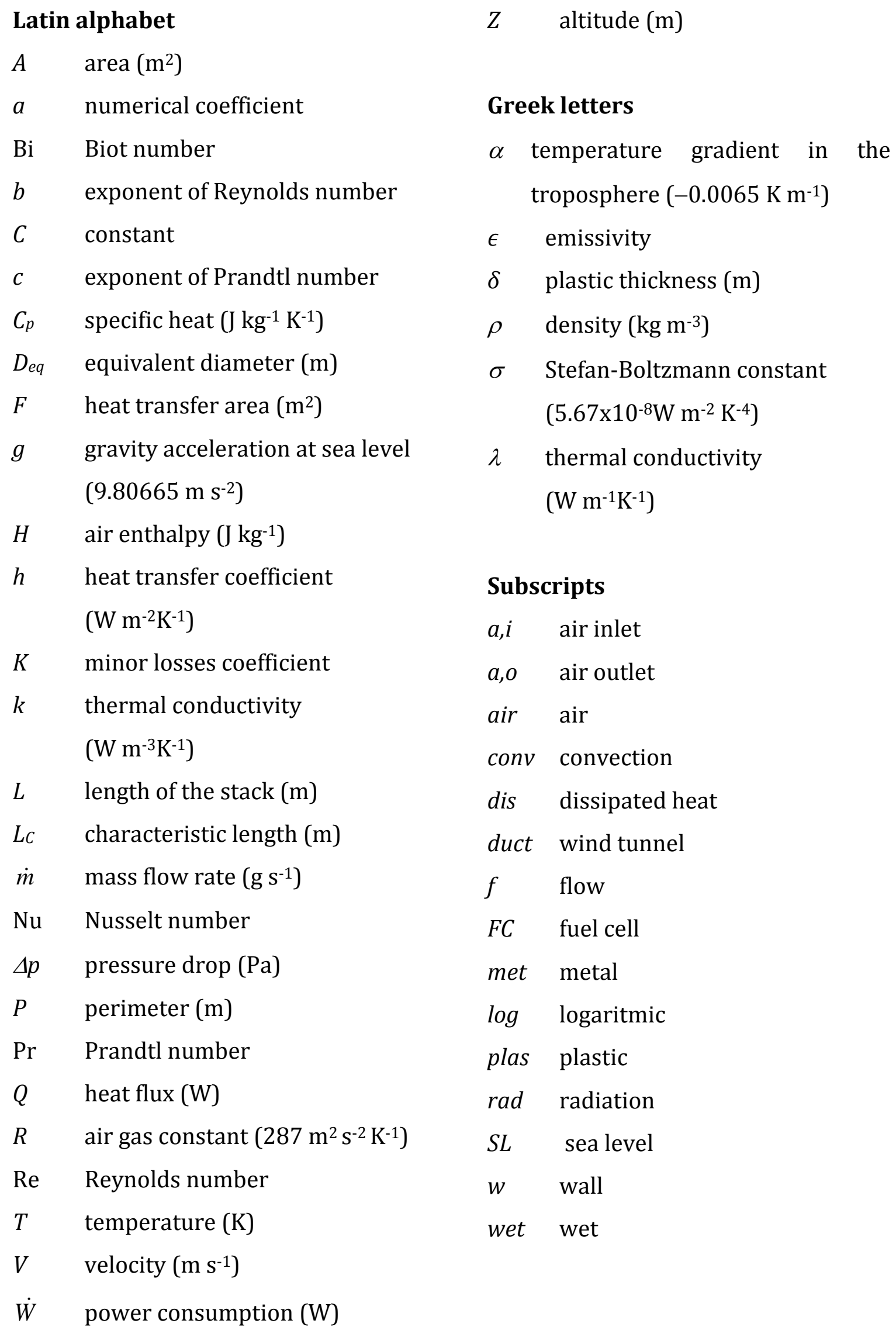




\section{Introduction}

An important percentage of the alarming amount of $\mathrm{CO}_{2}$ currently emitted to the atmosphere corresponds to the transport sector. In particular, aviation-generated $\mathrm{CO}_{2}$ is projected to grow in approximately $6 \%$ by 2050 , due to the increase in global travel demand [1]. Fuel cells can be a clean alternative for their use in the aeronautic sector [2]. For unmanned aerial vehicles (UAVs), powerplants based on proton exchange membrane fuel cells (PEMFCs) have been recently tested in flights of very short duration at low ceiling [3-5]. However, flights of small UAVs at a cruising altitude of $10 \mathrm{~km}$ pose some challenges related to the variation in atmospheric conditions, namely: very low atmospheric and partial oxygen pressures, temperature below $-50^{\circ} \mathrm{C}$, and very dry air humidity [6]. Efficiency and durability of a PEMFC is mainly affected by the accurate management of the mass and heat transfer processes that take place inside the device. Focusing on heat transfer, the working temperature of a PEMFC is normally adjusted to the one recommended by the membrane-electrode assembly (MEA) manufacturer. In the present research, a high temperature (HT) PEMFC stack is considered, which allows raising the operating temperature above $140^{\circ} \mathrm{C}$. This facilitates heat rejection due to the larger temperature difference between fuel cell and ambient environment [7]. As a result, the cooling system can be simpler, increasing the powerplant mass-specific and volume-specific power densities. This is a very important point for light UAVs where weight is an essential issue.

The heat transfer problem analyzed in the present research is to control the working temperature of a HT-PEMFC stack in the range from $140^{\circ} \mathrm{C}$ to $180^{\circ} \mathrm{C}$ when a constant electric power is demanded. The stack will be located inside the fuselage of the UAV, in order to protect the different elements of the powerplant from the very low ambient temperature during flights at an altitude of $10 \mathrm{~km}$. The UAV considered has a total airframe mass of $3 \mathrm{~kg}$, a wingspan of $4 \mathrm{~m}$, and the fuselage has a diameter of $200 \mathrm{~mm}$ and a length of $1.6 \mathrm{~m}$ [8]. A photo of this UAV is depicted in Fig. 1 in a low altitude flight with an internal combustion engine. 


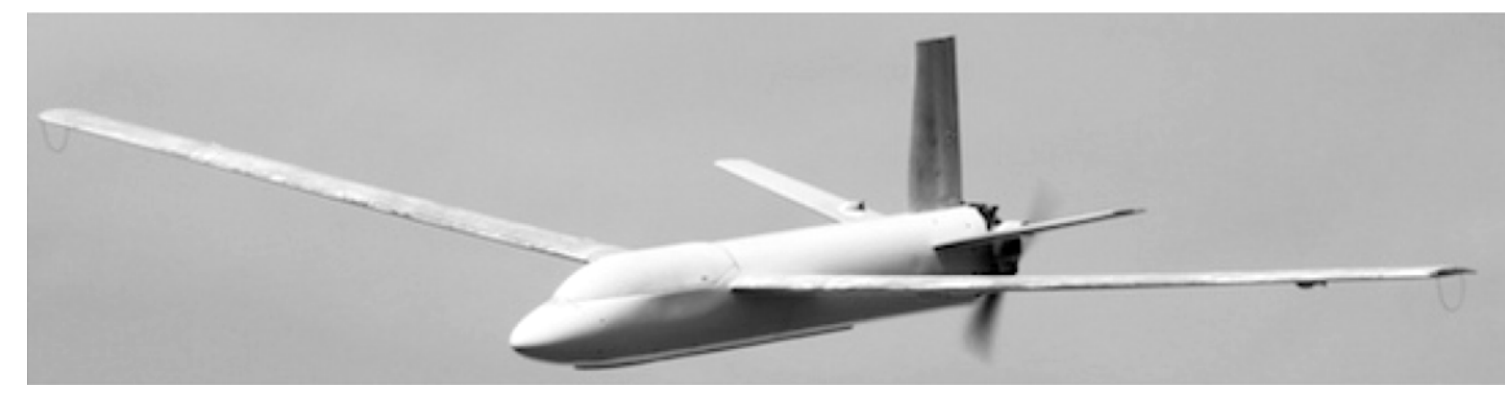

Figure 1. Photo of the UAV considered in the present research.

In a broader sense, the problem under study consists in the determination of the heat transfer coefficient of a prismatic three-dimensional object inside an enclosure. The experimental estimation of the heat transfer coefficient implies the measurement of the heat transferred by either direct (steady state) or indirect (transient) techniques [9]. Transient techniques involve the measurement of the temperature change with time at a location near to or at the body. An example of this method is the determination of the surface temperature analyzing the emitted radiation intensity and wavelength using infrared cameras [10,11]. A direct heat transfer measurement method is the energy supply technique, in which the temperature of a solid surface is measured while actively providing heat $[12,13]$. Other methods for the direct measurement of the heat transfer coefficient are the use of thin film heat flux sensors [14-16] or the one based on naphthalene sublimation that has been used to measure the convective heat transfer coefficient on the horizontal roof of a real building [17].

First studies on the determination of the heat transfer coefficient date back to the first half of the XX Century [18-20]. Since then, a large number of papers have been published describing correlations for the heat transfer coefficient as a function of the object geometry and the flow characteristics, as summarized in many textbooks [21,22]. Calculation of the heat transfer coefficient is widely reported in the literature for unconfined flows in an ample variety of application problems such as in machine tools and manufacturing processes [23-27], cooling of the human body [28-29], to refrigerate buildings [30-32] and electronic devices [33-35], or over cylinders or spheres [36-38]. In all these studies, either Nusselt number $(\mathrm{Nu})$ is expressed as a function of non-dimensional groups, typically Reynolds (Re) and Prandtl (Pr) numbers, or the heat transfer coefficient is given as a function of dimensional variables including temperature difference or coolant velocity. 
However, they are likely to be inaccurate in this case, because they do not consider form factors or tunnel blockage effects. In fact, many of them have been tested in this work with poor results. Another large group of studies refer to confined flows in channels or ducts [39-41], and to annular geometries as described in a recent review in [42], but they normally consider fully developed flow. In this study, the heat transfer from the HT-PEMFC stack occurs in a non-developed flow inside a reservoir with the walls quite close to the object. Besides, the object length in the flow direction is comparable to the dimensions in the direction normal to the flow, and $\mathrm{Re}$ numbers are in the range corresponding to laminar and transitionalturbulent regimes, constituting a rather particular case. All the tested correlations available in the literature have proven to be unsuitable.

The objective of this research is to obtain reliable and accurate models to calculate the heat transfer coefficient needed for the further design of the optimal cooling system of a high-temperature PEMFC stack that will be incorporated to the powerplant of a light UAV capable of reaching an altitude of 10,000 m using the energy supply technique. To this end, experiments are performed in two rectangular tunnels, for three different form factors, in conditions similar to those expected for the HT-PEMFC stack. For calculations, convective and radiative processes are considered. Different parameters are measured, such as air mass flow rate, inlet and outlet air temperatures, and wall temperatures for bipolar and endplates, among others.

\section{Heat transfer analysis. Non-dimensional considerations}

Once the HT-PEMFC stack is working under a stationary regime, the cooling system has to be capable of granting a stable temperature in the range between $140^{\circ} \mathrm{C}$ and $180^{\circ} \mathrm{C}$. In most cases, the coolant used is atmospheric air, and heat transfer mechanisms are convection and radiation. Initially it will be assumed that conduction between the different elements of the stack is sufficiently fast to characterize it by a single representative temperature. The accuracy of this assumption will be checked after obtaining the experimental results.

Excess heat generated for any specific stack power has to be extracted through the outer walls to keep a constant temperature. From an energy balance, once the 
system is in equilibrium, all the heat dissipated from the stack $\left(Q_{\text {dis }}\right)$ has to be equal to that absorbed by the air $\left(Q_{\text {air }}\right)$. It can be expressed as

$$
Q_{\text {dis }}=Q_{a i r}=\dot{m}_{a i r}\left(H_{a, o}-H_{a, i}\right)
$$

where $\left(\dot{m}_{\text {air }}\right)$ is the cooling air mass flow rate, while $H_{a, i}$ and $H_{a, o}$ are air inlet and outlet enthalpy respectively. Heat absorbed by the air is the sum of the convective and the radiative components

$$
Q_{\text {air }}=Q_{\text {conv }}+Q_{\text {rad }}
$$

The heat that the stack exchanges by radiation can be expressed as

$$
Q_{\text {rad }}=\sigma \epsilon_{F C} F_{F C}\left(T_{F C}^{4}-\bar{T}_{\text {air }}^{4}\right)
$$

where $\sigma$ is the Stefan-Boltzmann constant, $\epsilon_{F C}$ the stack emissivity, $F_{F C}$ the heat transfer area, $T_{F C}$ its absolute temperature, and $\bar{T}_{\text {air }}$ the air temperature averaged between inlet and outlet of the cooling system. Equation (3) includes the energy radiated by the stack and the radiative energy that it absorbs. It assumes that the stack absorption coefficient is equal to its emissivity, according to Kirchoff's law for a grey body. In this step, the HT-PEMFC stack is considered as a unique body, but as it is formed by different materials, Eq. (3) will later be modified.

Heat transferred by convection is defined by

$$
Q_{\text {conv }}=h F_{F C} \overline{\Delta T}_{l o g}
$$

where $h$ is the convective heat transfer coefficient, and $\overline{\Delta T}_{\text {log }}$ the mean logarithmic temperature difference that is calculated by

$$
\overline{\Delta T}_{\log }=\frac{\left(T_{w}-T_{a, i}\right)-\left(T_{w}-T_{a, o}\right)}{\ln \left(\frac{T_{w}-T_{a, i}}{T_{w}-T_{a, o}}\right)}
$$

$T_{a, i}$ and $T_{a, o}$ are the air inlet and outlet temperature, and $T_{w}$ the stack surface temperature,

The convective heat transfer coefficient $h$ for forced air flowing along an annular space surrounding a PEM fuel cell stack will depend on

$$
h=f\left(L, \lambda, \rho, V, D_{e q}, \mu, C_{p}\right)
$$

where $\lambda, \rho, \mu, C_{p}$ and $V$ are thermal conductivity, density, viscosity, specific heat and velocity of the cooling flow, respectively; $L$ is the stack length in the flow direction and $D_{e q}$ is the equivalent diameter of the cross-sectional area of the cooling fluid flow

$$
D_{e q}=\frac{4 A_{f}}{P_{w e t}}=\frac{4\left(A_{d u c t}-A_{F C}\right)}{P_{d u c t}+P_{F C}}
$$


in which $A$ and $P$ refer to area and perimeter, respectively. Subscripts " $f$ ", "wet", and "duct" indicate flow, wetted (whether in contact or not with the heat transfer surface), and the wind tunnel that encloses the stack acting as the cooling duct, respectively.

Applying the Buckingham pi theorem, four dimensionless groups are obtained: Nusselt, Reynolds and Prandtl numbers, and a form factor

$$
\begin{aligned}
& \mathrm{Nu}=\frac{h D_{e q}}{\lambda} \\
& \mathrm{Re}=\frac{\rho V D_{e q}}{\mu} \\
& \operatorname{Pr}=\frac{\mu C_{p}}{\lambda} \\
& \frac{D_{e q}}{L}
\end{aligned}
$$

Consequently,

$$
\mathrm{Nu}=f\left(\operatorname{Re}, \operatorname{Pr}, \frac{D_{e q}}{L}\right)
$$

The convective heat transfer coefficient is normally determined from empirical expressions, obtained experimentally for different heat transfer surfaces and flow configurations. However, the already discussed lack of models to accurately describe the heat transfer coefficient for the practical case studied in the present research, has forced to obtain the relation in Eq. (12), from a set of experiments specifically designed.

\section{Experimental set up}

The experimental set up in this problem includes a 3-D prismatic heat source that will simulate the HT-PEMFC stack, the wind tunnels that will act as the fuselage of the UAV, and the different elements used to measure the physical parameters relevant to the problem. A description of all of them will be given below.

\subsection{Fuel cell stack}

Although the fuel cell stack is still in the design stage, a brief summary of its main characteristics will be included. From aerodynamic calculations [8], it is considered that the power that has to be supplied by the electrochemical device is around $650 \mathrm{~W}$. The device will include commercial 5-layer high temperature Celtec $^{\circledR}$-P 1100 membrane electrode assemblies (MEAs) manufactured by BASF Fuel 
Cells with an active area of $81.28 \mathrm{~cm}^{2}$ and a working temperature of $160^{\circ} \mathrm{C}$. A polarization curve experimentally obtained in our research facilities for a single cell is presented in Fig. 2.

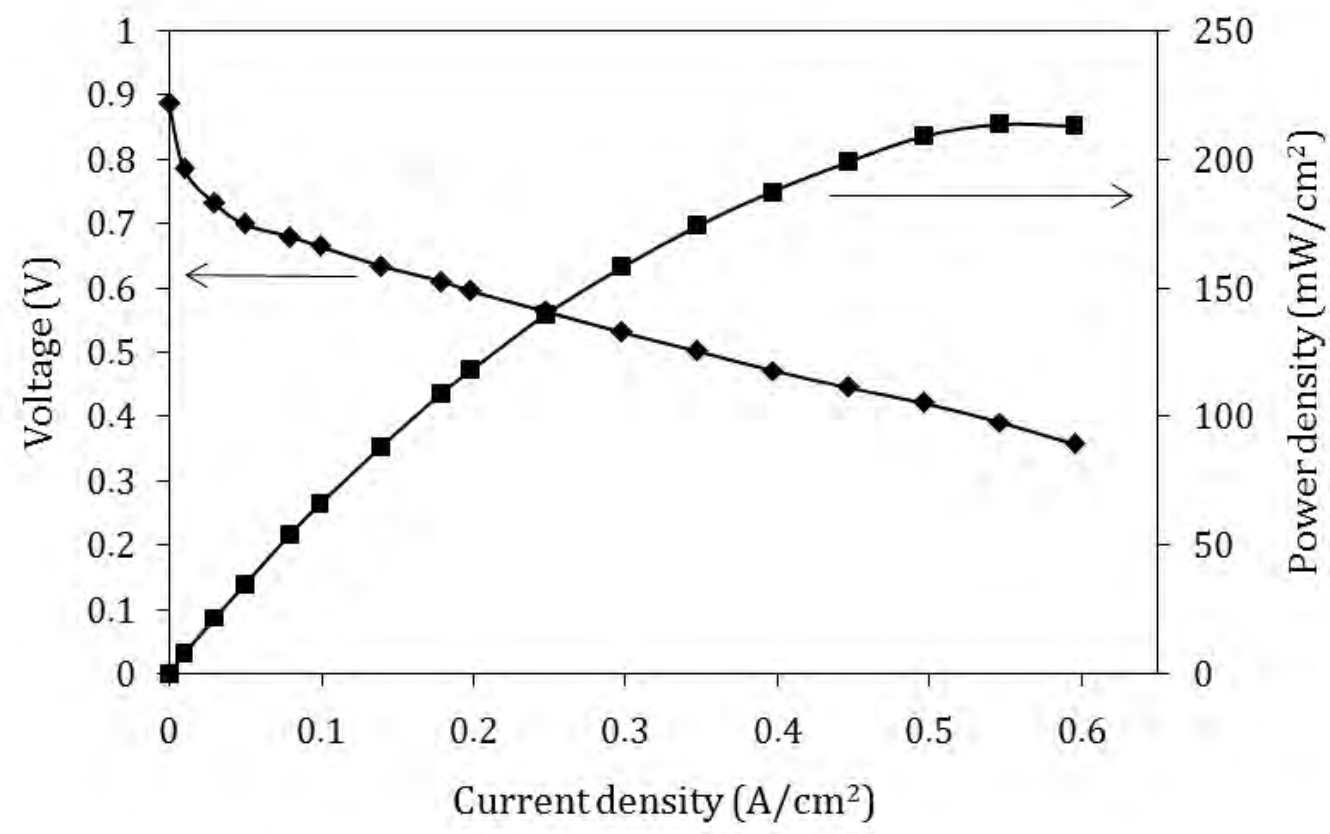

Figure 2. Polarization curve of a single cell.

Following the recommendations of the MEA's manufacturer, the operating point is fixed at a current density of $0.45 \mathrm{~A} \mathrm{~cm}^{-2}$ that yields a total current of 36.58 A. According to the polarization curve, a voltage of $0.45 \mathrm{~V}$ per cell is obtained for this current. Then, stacking 40 cells, the resulting fuel cell power is $658 \mathrm{~W}$. A sketch of the 40-cells stack is shown in Fig. 3, indicating the distribution of gases, the movement of the different species and electrons, and the heat transfer. As depicted in the zoomed-in section, each stack cell is formed by two plates that separate the individual cells, and a 5-layer MEA. This element is formed, from the outside, by two gas diffusion layers followed by the cathodic and anodic catalyst layers that are in close contact with the proton conductive polymeric membrane. The heat is generated at the catalyst layers of each cell.

To reduce the weight of the stack it will be constructed with monopolar aluminum plates, coated with chromium nitride by physical vapor deposition to protect them from corrosion $[43,44]$. Compared to graphite elements, the use of metallic plates improves the heat transfer process and simplifies the cooling system. The sealing and reactant gas supply systems will be similar to those in a $2.5 \mathrm{~kW}$ HT- 
PEMFC stack designed as a CHP-unit [45]. Finally very light endplates will be used to close the stack, manufactured in a high-temperature resistant plastic. With these elements, the total stack mass is $3.86 \mathrm{~kg}$, which could be further reduced using lighter materials e.g. a magnesium alloy for the monopolar plates.

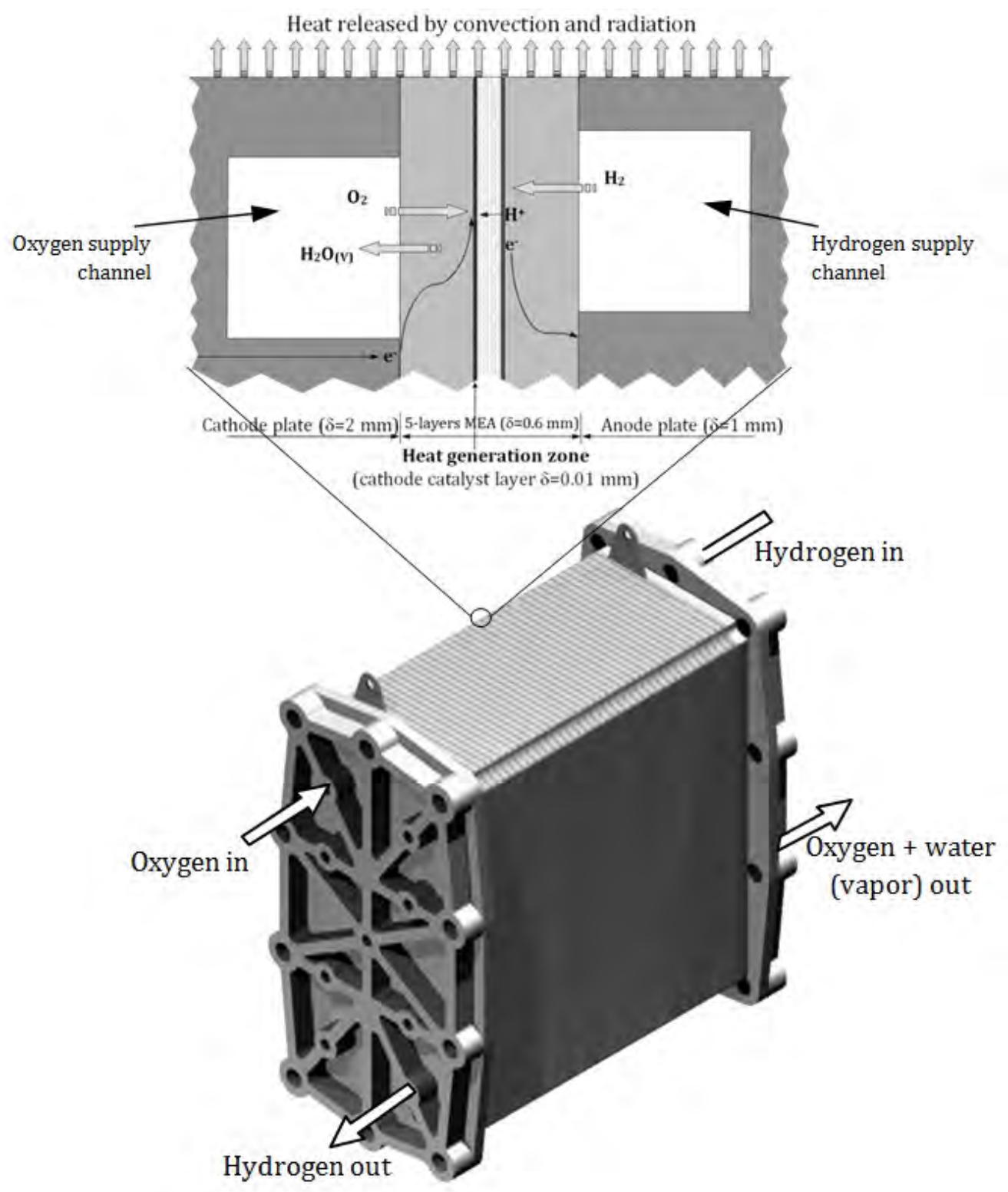

Figure 3. Sketch of the 40-cells stack with a zoomed-in section of one of the cells indicating the exchange of gases and heat transfer.

When studying the heat transfer process from the stack surface to the air, the way in which the electrochemical device is heated up is not relevant. To avoid work complexity, the stack is replaced by a solid aluminum block with a total length of $140 \mathrm{~mm}$, a height of $168 \mathrm{~mm}$, and a width of $81 \mathrm{~mm}$ exactly matching the dimensions 
of the 40-cell stack. The same plastic endplates are used in the experiments, attached to the metal block with passing threaded rods, in an identical way to that in the stack. It can be estimated that the heat released by the stack for the nominal working point is around $550 \mathrm{~W}$ [46]. The heat generation process is simulated introducing in the metal block two electrical resistance cartridges with a nominal power of $250 \mathrm{~W}$ each one. A photo of the device used in the heat transfer experiments is shown in Fig. 4.

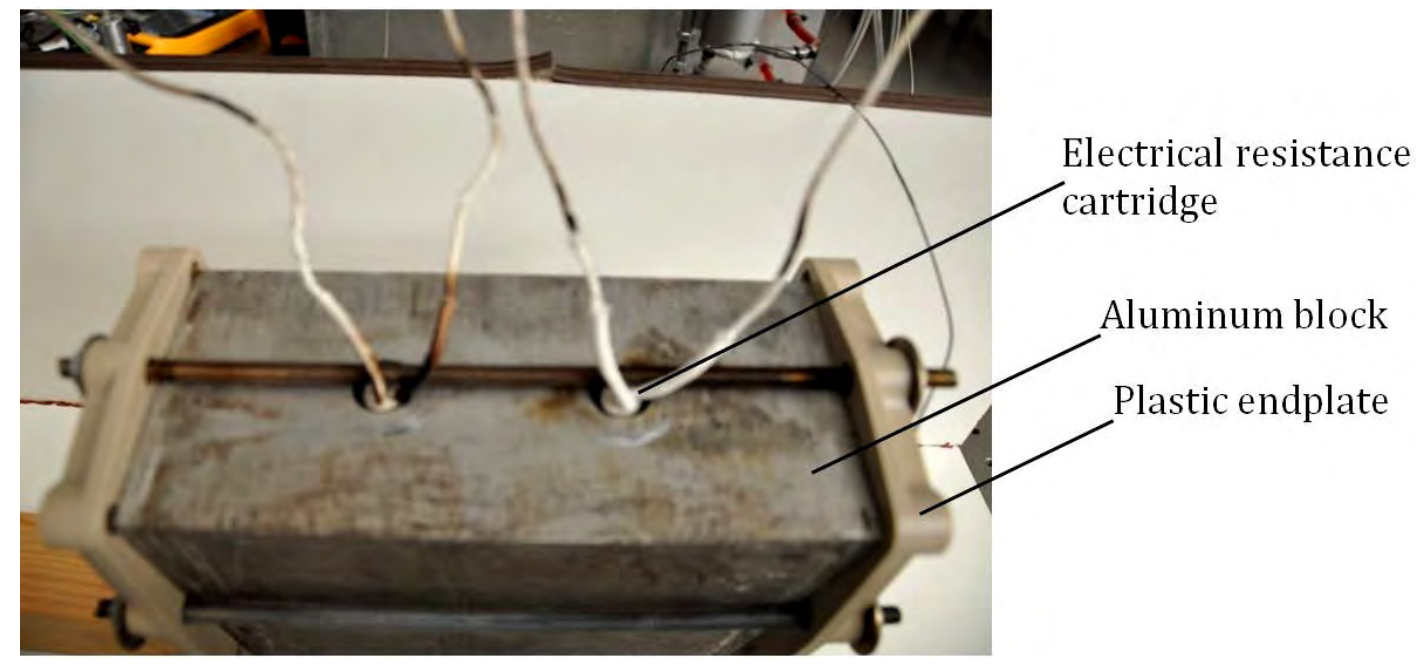

Figure 4. Device used in heat transfer experiments.

\subsection{Wind tunnels}

As the experiments are performed with the same length of the stack, $L$, the form factor $D_{e q} / L$ will be varied changing the value of $D_{e q}$, i.e. modifying the crosssectional area around the stack open to the cooling flow. Two wind tunnels are designed with the same length of $1.5 \mathrm{~m}$, similar to that of the UAV. The small one has a rectangular cross-section of $(115 \times 203) \mathrm{mm}^{2}$, which corresponds to a hydraulic diameter of $147 \mathrm{~mm}$. The second wind tunnel has a cross section of $(203 \times 235) \mathrm{mm}^{2}$, corresponding to a hydraulic diameter of $218 \mathrm{~mm}$, a bit larger than that of the actual UAV fuselage. In this case, different $D_{e q}$ values can be obtained by partially blocking the cross-sectional area with some obstacles. Three different form factor values are selected, $0.177,0.399$ and 0.575 , covering a wide range of experimental conditions. Images of the two wind tunnels are depicted in Fig. 5. 

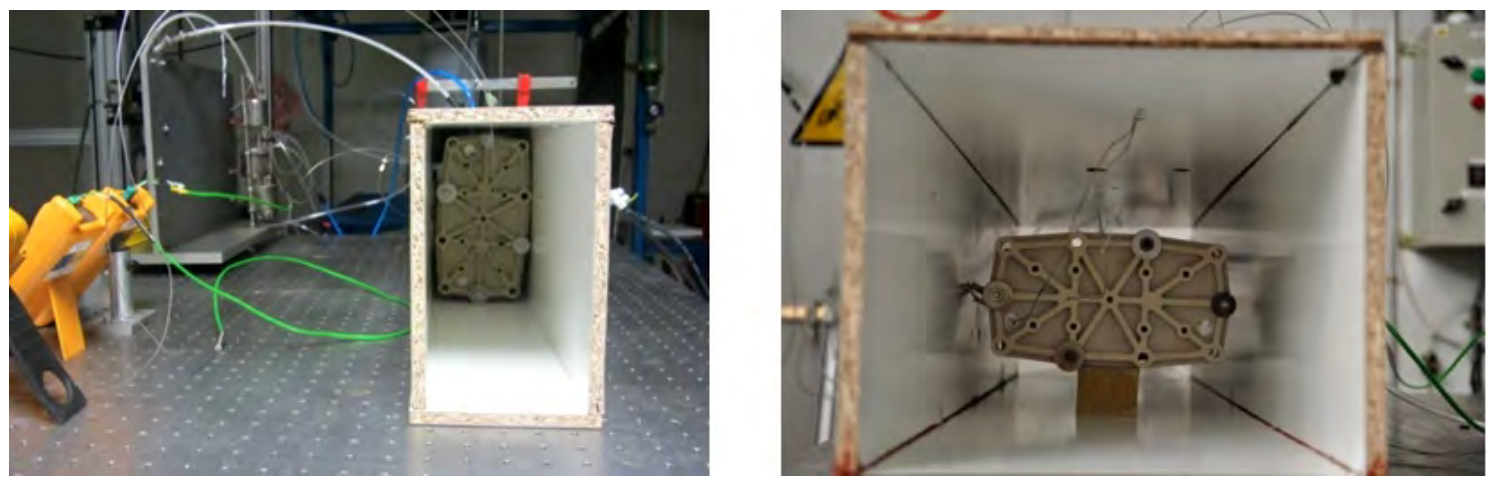

Figure 5. Images of the two wind tunnels used in the experiments taken from the exit zone. The positioning of the different instruments can also be observed.

The HT-PEMFC stack is placed at $1.25 \mathrm{~m}$ from the inlet sections, considering the actual possibilities inside the fuselage of the UAV. Besides, the zone where the stack is placed is isolated from room conditions by using a glass-fiber blanket. So, the heat transfer through the wall of the wind tunnel to the room can be neglected.

\subsection{Experimental measurements}

In order to use the set of Eqs. (1-12) to calculate the heat transfer coefficient, several parameters have to be measured in the experiments. These are: air inlet and outlet temperature, solid block metal temperature, temperature of the plastic endplates, air flow rate, air inlet pressure, pressure drop caused by the stack, and electric heat power.

According to the amount of heat that has been estimated to be released by the HT-PEMFC stack, a $10-100 \mathrm{Nm}^{3} \mathrm{~h}^{-1}$ flowmeter is selected. The air is supplied by the laboratory compressed air facility, which is formed by a multistage compressor capable of delivering a maximum flow rate of $100 \mathrm{~m}^{3} \mathrm{~h}^{-1}$ at 8 bar. During the tests it is observed that over $90 \mathrm{~m}^{3} \mathrm{~h}^{-1}$ the flow rate cannot be stabilized. On the other hand, below $30 \mathrm{~m}^{3} \mathrm{~h}^{-1}$ temperature of the plastic endplates rises over $300^{\circ} \mathrm{C}$, altering the thermal properties. These limits fix the range of air flow rates. Air inlet pressure and pressure drop are measured with inclined column manometers, with an accuracy of $1 \mathrm{~Pa}$. Four K-type thermocouples are used to measure the different temperatures. According to the manufacturer, they have a measurement range from $-100^{\circ} \mathrm{C}$ to $+1300^{\circ} \mathrm{C}$ with an accuracy of $\pm 0.1 \%$.

The experiments are performed according to the following procedure. Once 
the electrical resistance cartridges are connected, it is waited until temperature increases over a certain value. Then, a fixed air flow rate is supplied to the tunnel, and the measurement of the different parameters is registered every 30 or 45 minutes. The experiment finishes when the system reaches a steady state and the values of the metal, plastic and air outlet temperatures are stabilized. An example corresponding to an air flow rate of $40 \mathrm{Nm}^{3} \mathrm{~h}^{-1}$ and the form factor of 0.399 is depicted in Fig. 6.

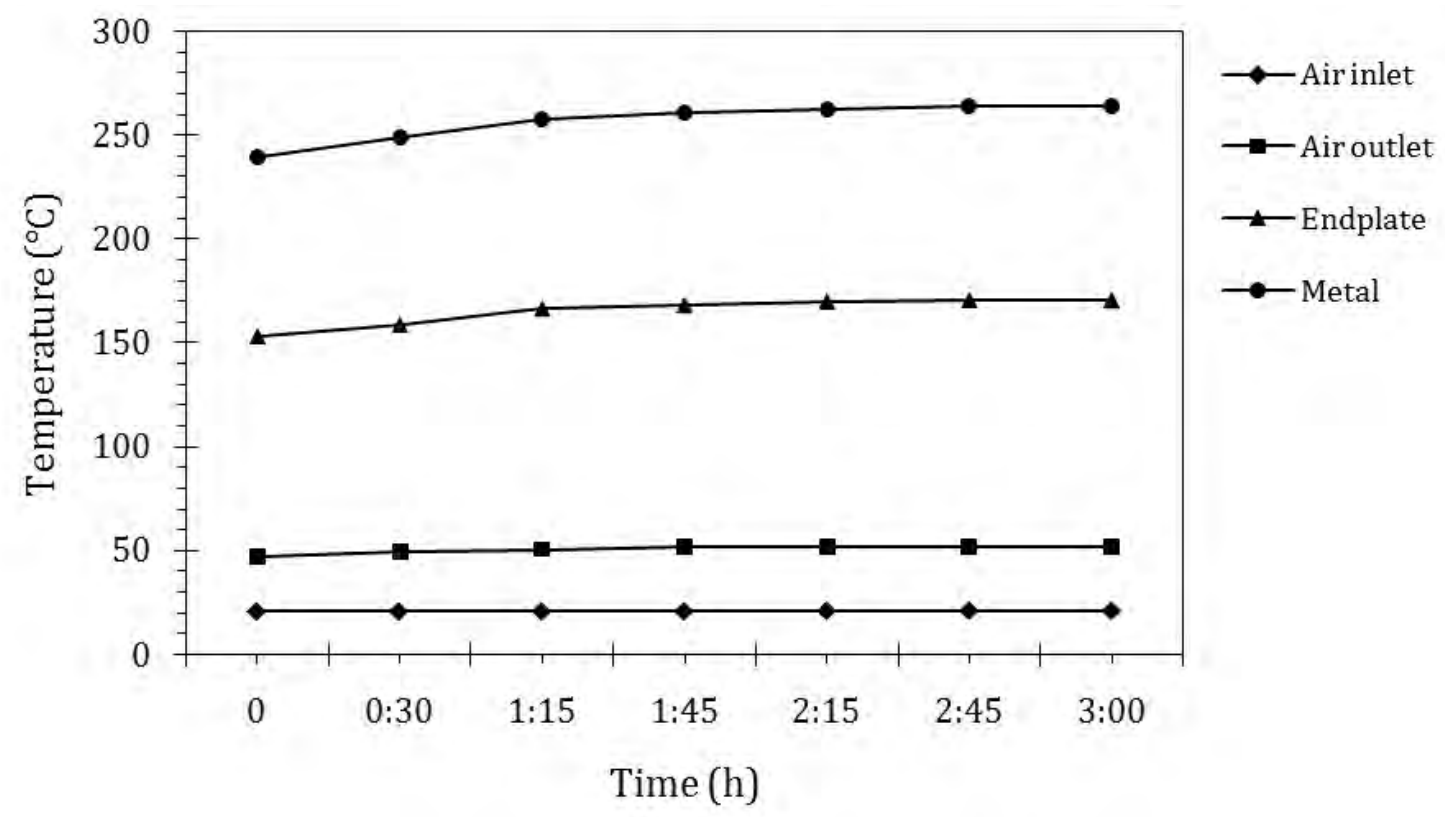

Figure 6. Example of the measurement procedure.

As the stack is formed by different materials it cannot be considered as a unique body. So, heat transfer radiation Eq. (3) has to be rewritten as,

$$
Q_{\text {rad }}=\sigma\left[\epsilon_{\text {met }} F_{\text {met }}\left(T_{\text {met }}^{4}-\bar{T}_{\text {air }}^{4}\right)+\epsilon_{\text {plas }} F_{\text {plas }}\left(T_{\text {plas }}^{4}-\bar{T}_{\text {air }}^{4}\right)\right]
$$

where subscripts "met" and "plas" refer to metal solid block and plastic endplates, respectively. Emissivity values taken from the literature [47] are $\epsilon_{m e t}=0.09$ for the aluminum block, and $\epsilon_{\text {plas }}=0.94$ for the plastic elements. Similarly, the stack wall temperature $\left(T_{w}\right)$, is calculated as an average value weighted by the heat transfer surface area of the two materials by,

$$
T_{w}=\frac{F_{m e t} T_{m e t}+F_{\text {plas }} T_{\text {plas }}}{F_{\text {met }}+F_{\text {plas }}}
$$

Another important consideration in the experiments is that as the air will heat up, all physical properties will have to be calculated as a function of temperature. Under these circumstances the range of Pr values is relatively limited. Another 
independent variable that can be controlled is the Reynolds number. Change in this parameter is mainly achieved by variations in equivalent diameter $D_{e q}$, and in air velocity, which in turn depends on flow area and air flow rate supplied to the system. Hence, Re will be a selectable parameter in a range determined by the experimental conditions.

\section{Experimental results and discussion}

A total of 43 experimental runs are completed, each one with a duration ranging from 2 to 4 hours. To determine when a steady state has been reached, the temporal evolution of the temperatures is controlled.

\begin{tabular}{|c|c|c|}
\hline Non-dimensional group & Minimum value & Maximum value \\
\hline $\mathrm{Nu}$ & 14.74 & 91.13 \\
\hline $\mathrm{Re}$ & 1194 & 6750 \\
\hline $\mathrm{Pr}$ & 0.72 & 0.73 \\
\hline$\frac{D_{e q}}{L}$ & 0.177 & 0.575 \\
\hline
\end{tabular}

Table 1. Value ranges for the non-dimensional groups.

Once values are processed, both radiative and convective heat, as well as the heat transfer coefficient are calculated. To this end, a numerical code that includes all equations is implemented with the Engineering Equation Solver (EES) commercial software [48]. EES is a numerical solver and, in most problems, it uses an iterative procedure to solve the equations. Parameters have been configured so that iterations are stopped when relative residuals are $<10^{-6}$, or when the change in variables is $<10^{-9}$.To obtain the numerical solution a golden section search method is used [49]. All dimensionless groups can now be calculated. The value ranges for all of them are presented in Table 1. Similarly, maximum and minimum values for radiation heat, convection heat absorbed by the coolant, and convective heat transfer coefficient are summarized in Table 2.

With the range of values for $h$, the accuracy of having neglected the heat conduction process can be assessed. This information can be obtained from the Biot number, defined as 
$\mathrm{Bi}=\frac{h L_{C}}{k}$

\begin{tabular}{|l|c|c|c|}
\hline \multicolumn{1}{|c|}{ Parameter } & Unit & Minimum & Maximum \\
\hline Radiation heat & $\mathrm{W}$ & 26.4 & 120.7 \\
\hline Convection heat & $\mathrm{W}$ & 370.3 & 483.5 \\
\hline Convective heat transfer coefficient & $\mathrm{W} \mathrm{m}^{-2} \mathrm{~K}^{-1}$ & 8.0 & 44.0 \\
\hline
\end{tabular}

Table 2. Value range for some of the calculated parameters.

where, $L_{c}$ is the characteristic length defined as the volume of the body divided by its surface area, and $k$ is the thermal conductivity of the object. For the experimental conditions and materials of the present research, the Biot number ranges from 0.0007 to 0.004 . As the Bi number is well below 0.01, temperature gradients inside the object can be neglected because heat conduction is indeed much faster than heat convection away from its surface [50]. It is then reasonable to assume that temperature and heat transfer are constant throughout the object.

\subsection{Heat transfer coefficient models}

Figure 7 shows the relation between $\mathrm{Nu}$ and $\mathrm{Re}$, derived from the experimental measurements.

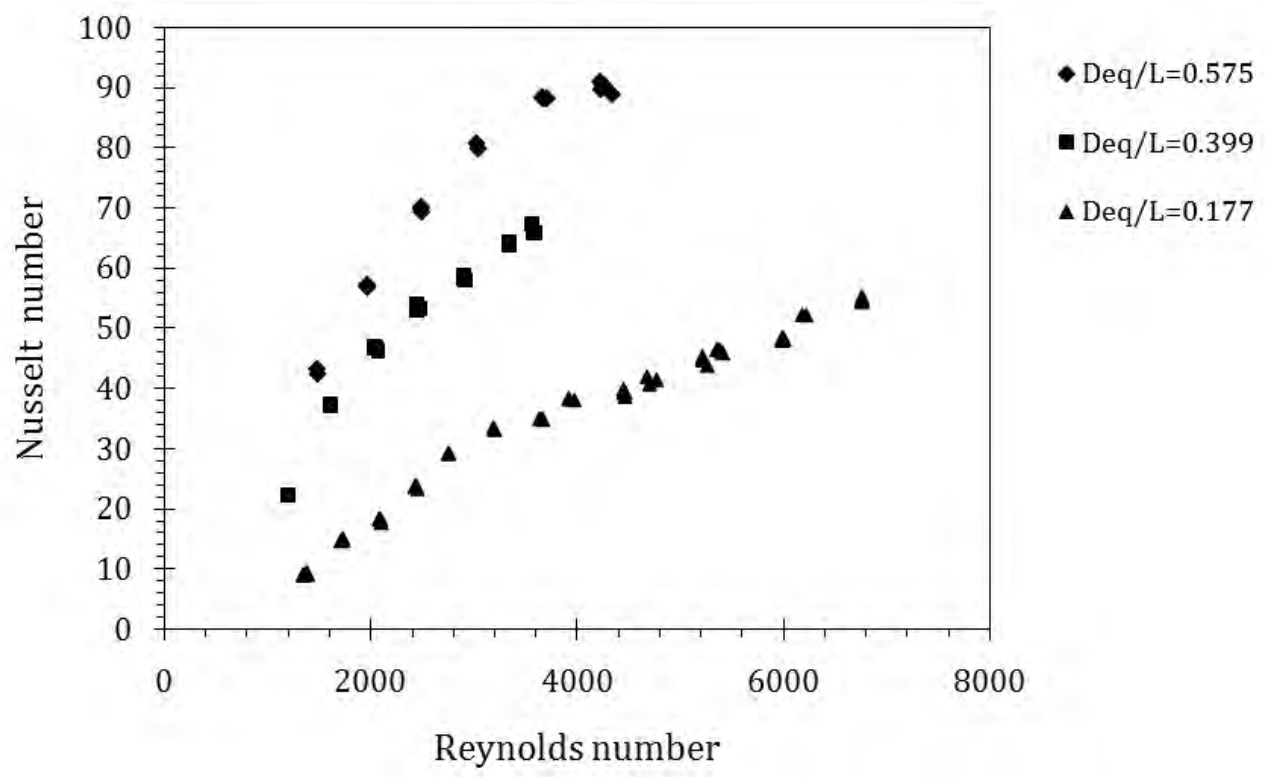

Figure 7. Relation between $\mathrm{Nu}$ and Re numbers for the three form factors. 
As already stated, the range of Pr values is quite short, and it will be assumed that $\mathrm{Nu}$ depends on $\mathrm{Pr}$ to the $1 / 3$ power $[22,47,51]$. If the relation $\mathrm{Nu}(\mathrm{Pr})^{-1 / 3}$ vs. $\operatorname{Re}$ is represented in a logarithmic plot it is verified that the points can be fitted to straight lines. However, two separate zones can be distinguished, for which the lines have a different slope.

For $\operatorname{Re}\left(\frac{D_{e q}}{L}\right) \geq 640$ a best fit using the CurveExpert Professional software [52] can be obtained for

$$
\operatorname{NuPr}^{-(1 / 3)}=0.6768 \operatorname{Re}^{0.6566}\left(\frac{D_{e q}}{L}\right)^{0.7610}
$$

with a standard error of $3.81 \times 10^{-2}$ and a regression coefficient of 0.994 .

For $\operatorname{Re}\left(\frac{D_{e q}}{L}\right) \leq 560$ the best fit is obtained for

$$
\operatorname{NuPr}^{-(1 / 3)}=0.001248 \operatorname{Re}^{1.5667}\left(\frac{D_{e q}}{L}\right)^{1.3082}
$$

with a standard error of $5.02 \times 10^{-2}$ and a regression coefficient of 0.993 .

These two expressions can be rewritten in the form

$$
\frac{\mathrm{Nu}}{\operatorname{Pr}^{(1 / 3)}}\left(\frac{D_{e q}}{L}\right)^{b-c}=a\left(\operatorname{Re} \frac{D_{e q}}{L}\right)^{b}
$$

where $a$ is the multiplicative numerical coefficient in the right hand side of Eqs. (16) and (17), $b$ the exponent of the Reynolds number, and $c$ the exponent of the form factor $\left(D_{e q} / L\right)$. With this reformulation, the plot in Fig. 8 is obtained.

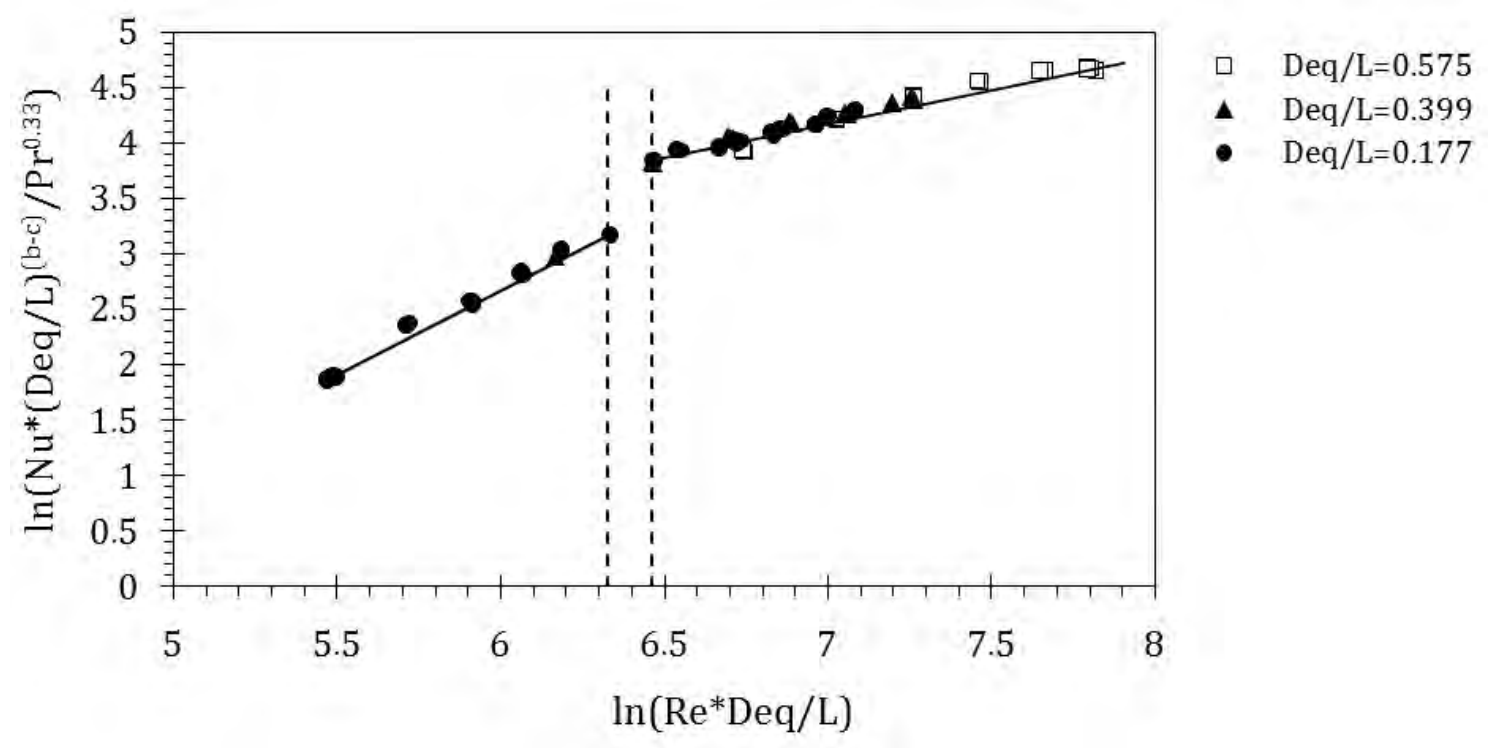

Figure 8. Dependence of the non-dimensional groups collapsed into two straight lines. 
As can be observed, the dependence of the non-dimensional groups is collapsed in two straight lines. It is to be noted that both slope and intersect point of the two straight lines are notably different. Considering that the variable represented in the horizontal axis is the product of the Reynolds number by the form factor $\left(D_{e q} / L\right)$, the existence of the two zones is associated to a transition between laminar and transition-turbulent regime according to the range of Re numbers, coupled with the development of the boundary layer dependent on the form factor group.

Approximating the exponents to simple fractions, Eqs. (16) and (17) can be rewritten as

$$
\mathrm{Nu}=0.6155 \operatorname{Re}^{(2 / 3)}\left(\frac{D_{e q}}{L}\right)^{(3 / 4)} \operatorname{Pr}^{(1 / 3)}
$$

for $\operatorname{Re}\left(\frac{D_{e q}}{L}\right) \geq 640$ and

$$
\mathrm{Nu}=0.002149 \operatorname{Re}^{(3 / 2)}\left(\frac{D_{e q}}{L}\right)^{(4 / 3)} \operatorname{Pr}^{(1 / 3)}
$$

for $\operatorname{Re}\left(\frac{D_{e q}}{L}\right) \leq 560$.

The fit to the experimental measurements using Eqs. (16) and (17) has an average error of 3.34\%. Using the simplified Eqs. (19) and (20), the error slightly increases to $4.33 \%$.

For the $\operatorname{Re}\left(\frac{D_{e q}}{L}\right) \geq 640$ region, the obtained dependence of the Nusselt number on the form factor is similar to that described in other previous studies reported in the literature for confined flow configurations [53,54]. However, for $\operatorname{Re}\left(\frac{D_{e q}}{L}\right) \leq 560$, our results indicate a stronger influence of the form factor than the one normally reported in other papers $[19,55]$. It should be noted that if the models in the literature are used, errors around 50\% are obtained when estimating the heat transfer coefficient even when they have been obtained for flow configurations similar (although not identical) to the tested one, but different flow conditions.

\subsection{Model validation}

With all the equations described up to this point, starting from a reduced set of input values (heat generated by the stack, air flow rate and air inlet temperature), an average stack surface temperature and air outlet temperature can be calculated using the EES numerical code. However, if the temperature for the plastic endplates 
and that for the metal stack surface have to be determined separately, a heat balance has to be sequentially applied to each one of these elements. In this way, intermediate temperatures and heat transfer coefficients can be obtained for the front plastic endplate, the metal surface in the middle, and the rear endplate.

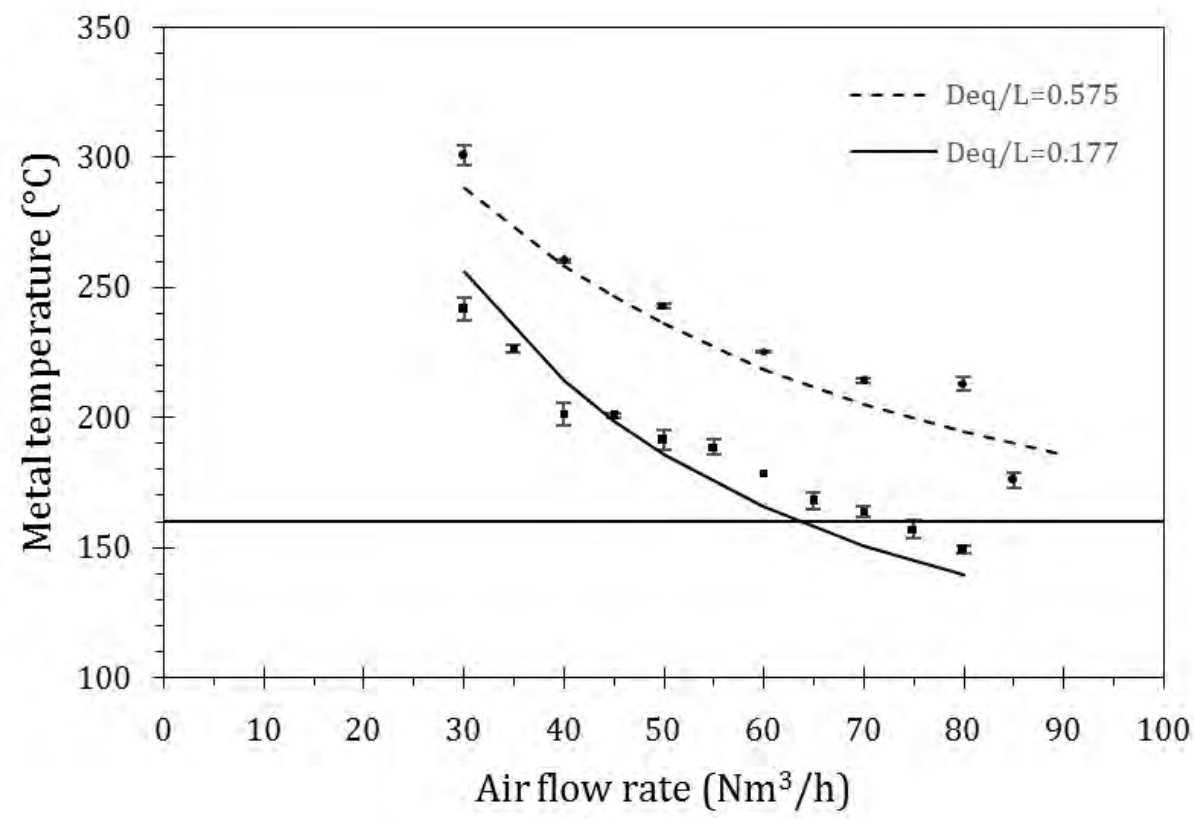

Figure 9. Predicted (lines) and experimental (symbols) metal temperatures at sea level.

Figure 9 shows both experimental and predicted metal temperature as a function of the cooling air flow rate at sea level conditions. All experimental points have been replicated at least five times. Error between predicted and measured values is below $10 \%$ in all cases. As expected, stack cooling becomes more difficult as $D_{e q} / L$ increases, due to the decrease in air velocity and, hence, in the convective heat transfer coefficient.

If the fuel cell stack is going to be installed in a UAV, it is interesting to determine the dependence of the required cooling air mass flow rate on altitude $(Z)$. Air density and temperature variation will be described by the formulas of a standard ISO atmosphere [56],

$$
\begin{aligned}
& T=T_{S L}+\alpha Z \\
& \rho=\rho_{S L}\left(1+\frac{\alpha Z}{T_{S L}}\right)^{-\frac{g}{\alpha R}-1}
\end{aligned}
$$


These expressions are applicable up to $10,000 \mathrm{~m}$. In them, $\rho_{S L}$ and $T_{S L}$ are the density and temperature values at sea level $\left(1.225 \mathrm{~kg} \mathrm{~m}^{-3}\right.$ and $288.15 \mathrm{~K}$ respectively), $g$ is the gravity acceleration at sea level assumed to be constant and equal to $9.80665 \mathrm{~m} \mathrm{~s}^{-2}, R$ is the air gas constant $\left(287 \mathrm{~m}^{2} \mathrm{~s}^{-2} \mathrm{~K}^{-1}\right)$, and $\alpha$ is the temperature gradient in the troposphere taken to be $-0.0065 \mathrm{~K} \mathrm{~m}^{-1}$.

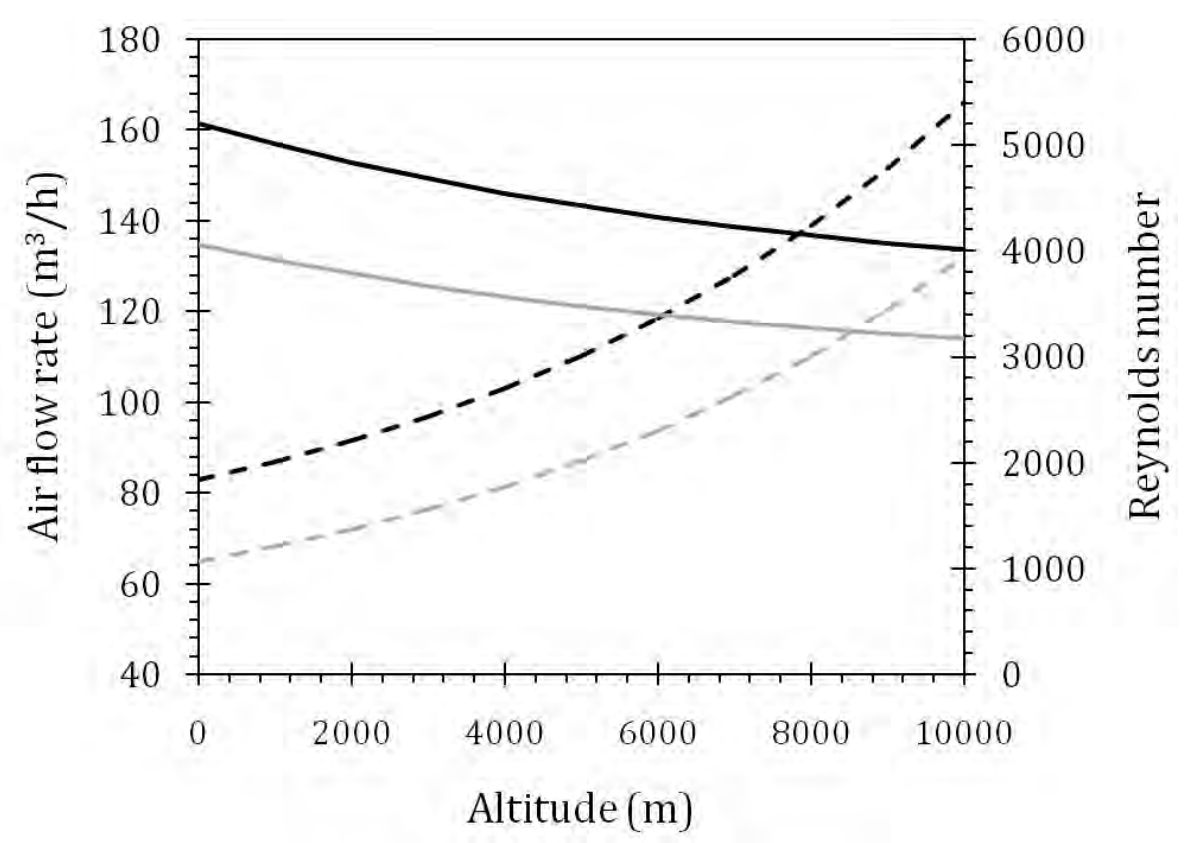

Figure 10. Cooling air flow rate (dotted lines) and Reynolds number (solid lines) for two different heat released powers. Grey color corresponds to $500 \mathrm{~W}$, and black to $600 \mathrm{~W}$.

Results depicted in Fig. 10 are finally obtained for two heat released power values, $500 \mathrm{~W}$ and $600 \mathrm{~W}$. The change in air properties with altitude leads to an increase in both air velocity and volumetric flow rate required for a suitable cooling. However, as the air density decreases, the cooling air flow rate also decreases with height. In the same way, as the air velocity increase is smaller than the density variation, Re also decreases.

\subsection{Optimization of the cooling flow section}

Variations in the cooling flow section are influential on the heat transfer, because the form factor, $D_{e q} / L$, and the convective heat transfer coefficient can be modified. On the other hand, pressure losses in the cooling flow also depend on the flow cross- 
sectional area. The required cooling flow rate, taking into account pressure losses, determines the power required to circulate the flow along the cooling circuit:

$$
\dot{W}=\Delta p_{f} V A_{\text {air }}
$$

Pressure losses $\Delta p_{f}$ can be evaluated according to

$$
\Delta p_{f}=\rho K \frac{V^{2}}{2}
$$

where friction losses have been neglected compared to those due to sudden changes in flow section and direction. The coefficient of minor losses, $K$, can be considered to be a function of the ratio between the wind tunnel section and the flow section around the stack

$$
K=C\left(1-\frac{A_{\text {air }}}{A_{\text {duct }}}\right)
$$

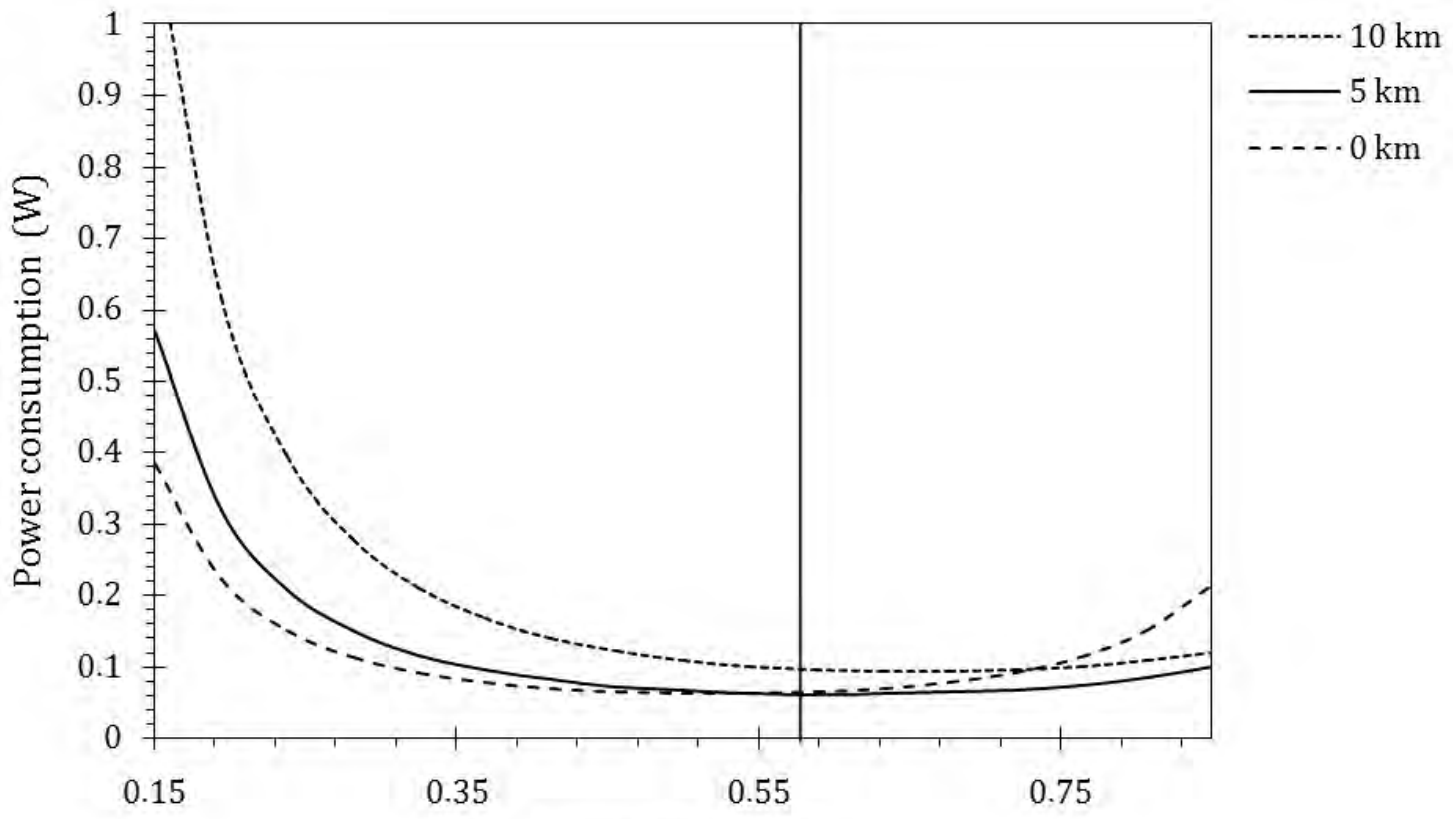

Form factor, $D_{e q} / L$

Figure 11. Behavior of the power consumption of the air cooling system.

From the experimental measurements, an average $C$ value of $10.73 \pm 0.4$ is obtained. It should be noted that this result does not agree with those reported in the literature for either an expansion or a contraction, because the tested configuration includes a combination of contractions, expansions and changes in flow direction. Adding these equations to the EES numerical code, the form factor that minimizes the cooling system power consumption can be obtained. As can be observed in Fig. 11, the curves have a relatively flat region near the minimum, so for 
form factors ranging between 0.35 and 0.55 low power will be required to cool the stack down. Obviously, the selected form factor $\left(D_{e q} / L\right)$ has to be compatible with the space available in the aircraft frame, usually quite limited. For this reason, it will be unpractical to further increase the flow cross section. The vertical line marks the maximum form factor used in the experimental measurements.

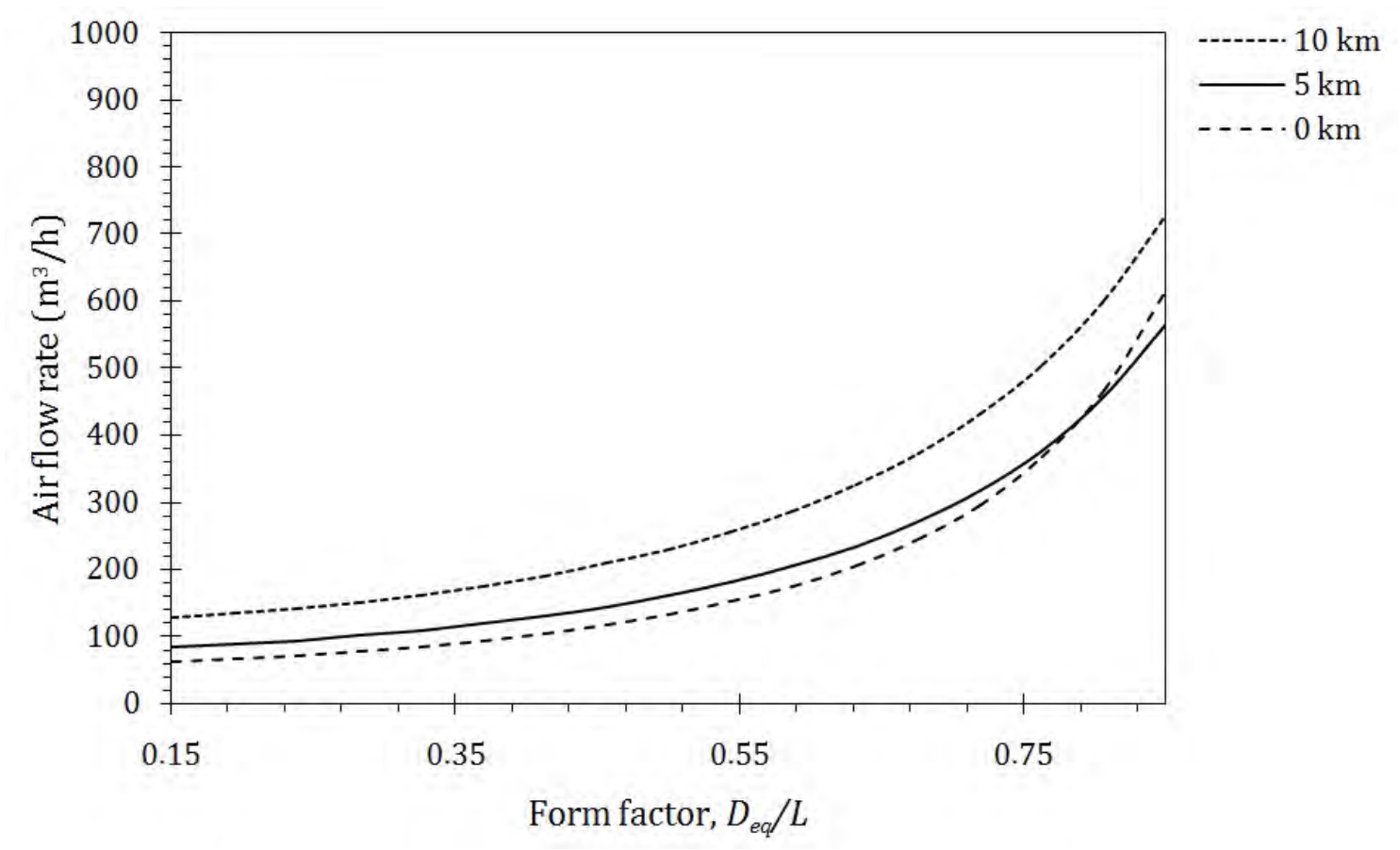

Figure 12. Behavior of air volumetric flow rate.

The required air flow rate as a function of the form factor in shown in Fig. 12. It is to be noted that for the form factor range considered, the corresponding air velocity at an altitude of $10 \mathrm{~km}$ is always below $7 \mathrm{~m} / \mathrm{s}$. This means that cooling the stack down to the operating temperature $\left(160^{\circ} \mathrm{C}\right)$, can be achieved either by active or passive systems. For the passive strategy, the velocity of the air flow induced by the movement of the UAV during flight can be used for cooling purposes. Axial compact fans with very low power consumption can be considered for the active method [57-59]. It should be noted that the calculated aircraft stall velocity when flying at $10 \mathrm{~km}$ is above $25 \mathrm{~m} \mathrm{~s}^{-1}$. In any case, the way to pass the air flow through the fuselage of the UAV has to be carefully designed accounting for specific aerodynamic considerations. 


\section{Conclusions}

A set of experiments has been completed to determine the convective heat transfer coefficient to cool a HT-PEMFC stack down installed in the fuselage of an UAV. The calculated heat transfer coefficient varies from 8 to $44 \mathrm{~W} \mathrm{~m}^{-2} \mathrm{~K}^{-1}$. Two new models have been obtained that allow the accurate calculation of the Nusselt number as a function of the three relevant non-dimensional groups, $\mathrm{Re}, \mathrm{Pr}$, and form factor $\left(D_{e q} / L\right)$. If other models available in the literature are used, errors around $50 \%$ are obtained when estimating the heat transfer coefficient. With a non-dimensional approach, results obtained at sea level are suitably extrapolated for a target altitude of $10 \mathrm{~km}$. Using a numerical code specifically developed, the cooling flow section is optimized, resulting in form factors from 0.35 to 0.55 . This range will ensure a cooling system with low power consumption, and is compatible with the space availability in the actual aircraft fuselage. Results indicate that both passive and active cooling strategies could be practically considered.

The developed procedure and the models obtained (considering the validity range) will be applicable for any situation in which a fuel cell stack located in an enclosure is cooled down by an air flow surrounding it. This is a typical situation for either high-temperature or low-temperature PEMFC stacks used in transportation or in combined heat and power units.

\section{Acknowledgments}

This work has been funded by the Secretariat of State for Research of the Spanish Ministry of Economy and Competitiveness under project ENE2012-38642-C0201/CON.

\section{References}

[1] International Industry Working Group. Commercial aircraft design characteristics - trends and growth projections, fifth ed., 2007.

[2] Hydrogen, Energy and Fuel Cells - A vision for our future, high level group for hydrogen and fuel cells, Summary Report, June 2003.

[3] T.H. Bradley, B.A. Moffitt, D.N. Mavris, D.E Parekh, Development and experimental characterization of a fuel cell powered aircraft, J. Power Sources 
171 (2007) 793-801.

[4] G.D. Rhoads, N.A Wagner, B.J. Taylor, D.B. Keen, T.H. Bradley, Design and flight test results for a 24 hour fuel cell unmanned aerial vehicle, 8th Annual Int. Energy Conv. Eng. Conf., Nashville, USA, AIAA paper 2010-6690 (2010).

[5] T. Kim, S. Kwon, Design and development of a fuel cell-powered small unmanned aircraft, Int. J. Hydrogen Energy 37 (2012) 615-622.

[6] T. Hauf, P. Shulte, R. Alheit, H. Schlager, Rapid vertical trace gas transport by an isolation midlatitude thunderstorm, J. Geophys. Res. 100 (1995) $22,957-22,970$.

[7] J. Zhang, Z. Xie, J. Zhan, Y. Tang, Ch. Song, T. Navessin, Z. Shi, D. Song, H. Wang, D.P. Wilkinson, Z-Sh. Liu, S. Holdcroft, High temperature PEM fuel cells, J. Power Sources, 160 (2006) 872-891.

[8] J. Renau, A. Lozano, J. Barroso, J. Miralles, J. Martín, F. Sánchez, F. Barreras, Use of fuel cell stacks to achieve high altitudes in light unmanned aerial vehicles, Int. J. Hydrogen Energy, DOI: 10.1016/j.ijhydene.2015.02.071.

[9] W. Rohsenow, J. Hartnett, Y. Cho, Handbook of Heat Transfer, McGraw-Hill Professional, USA, 1998.

[10] S. Harmand, B. Watel, B. Desmet, Local convective heat exchanges from a rotor facing a stator, Int. J. Therm. Sci. 39 (2000) 404-413.

[11] M. Mori, L. Novak, M. Sekavcnik, Measurements on rotating blades using thermography, Exp. Therm. and Fluid Sci. 32 (2007) 387-396.

[12] T.V. Radhakrishnan, A.K. Verma, C. Balaji, S.P. Venkateshan, An experimental and numerical investigation of mixed convection from a heat generating element in a ventilated cavity, Exp. Therm. and Fluid Sci. 32 (2007) 502-520.

[13] D.A. Howey, A.S. Holmes, K.R. Pullen, Radially resolved measurement of stator heat transfer in a rotor-stator disc system, Int. J. Heat and Mass Transf. 53 (2010) 491-501.

[14] F.W. Hartwig, C.A. Bartsch, H. McDonald, Miniaturised heat meter for steady state aerodynamic heat transfer measurements, J. Aeronautical Sci. (1957) 239.

[15] M.G. Dunn, J. Kim, W.J. Rae, Investigation of the heat-island effect for heat flux measurements in short duration facilities, Trans. ASME J. Turbomach. 119 (4) (1997) 753-760. 
[16] T.S. O’Donovan, D.B. Murray, Jet impingement heat transfer - part I: mean and root mean square heat transfer and velocity distributions, Int. J. Heat and Mass Transf. 50 (2007) 3291-3301.

[17] J. Shao, J. Liu, J. Zhao, W. Zhang, D. Sun, Z. Fu, A novel method for full-scale measurement of the external convective heat transfer coefficient for building horizontal roof, Energy and Build. 41 (2009) 840-847.

[18] G.I. Taylor, Distribution of velocity and temperature between concentric rotating cylinders, Proc. Royal Soc. London A151 (1935) 494-518.

[19] E.N. Sieder, C.E. Tate, Heat transfer and pressure drop of liquids in tubes, Ind. Eng. Chem. 28 (1936), 1429.

[20] A.S: Foust, G.A. Christian, Non-boiling heat transfer coefficients in annuli, Am. Inst. Chem. Eng. 36 (1940) 541-554.

[21] R.H. Perry, D.W. Green, J.O. Maloney, Perry's chemical engineers' handbook, seventh ed., McGraw Hill, New York, 1997.

[22] K.F. Pavlov, P.G. Romanskov, A.A. Noskov, Examples and Problems to the Course of Unit Operations of Chemical Engineering (in Spanish), first edition, MIR, Moscow, 1979.

[23] G. Cheng, F.Han, Z. Feng, Experimental determination of convective heat transfer coefficient in WEDM, Int. J. Machine Tools and Manuf. 47 (2007) 1744-1751.

[24] D. Umbrelloa, L. Filice, S. Rizzuti, F. Micari, On the evaluation of the global heat transfer coefficient in cutting, Int. J. Machine Tools and Manuf. 47 (2007) 1738-1743.

[25] J.0. Aweda, M.B. Adeyemi, Experimental determination of heat transfer coefficients during squeeze casting of aluminium, J. Mater. Process. Tech. 209 (2009) 1477-1483.

[26] T.-H. Hung, P.-W. Tsai, F.-K. Chen, T.-B. Huang, W.-L. Liu, Measurement of heat transfer coefficient of boron steel in hot stamping, Procedia Eng. 81 (2014) 1750-1755.

[27] K. Zhao, B. Wang, Y. Chang, X. Tang, J. Yan, Comparison of the methods for calculating the interfacial heat transfer coefficient in hot stamping, App. Therm. Eng. 79 (2015) 17-26.

[28] Y. Kurazumi, T. Tsuchikawa, J. Ishii, K. Fukagawa, Y. Yamato, N. Matsubara, 
Radiative and convective heat transfer coefficients of the human body in natural convection, Build. and Environ. 43 (2008) 2142-2153.

[29] N. Luo, W.G. Weng, M. Fu, J. Yang, Z.Y. Han, Experimental study of the effects of human movement on the convective heat transfer coefficient, Exp. Therm. and Fluid Sci. 57 (2014) 40-56.

[30] S. Leenknegt, R. Wagemakers, W. Bosschaerts, D. Saelens, Numerical study of convection during night cooling and the implications for convection modeling in Building Energy Simulation models, Energy and Build. 64 (2013) 41-52.

[31] K. Arendt, M. Krzaczek, Co-simulation strategy of transient CFD and heat transfer in building thermal envelope based on calibrated heat transfer coefficients, Int. J. Therm. Sci. 85 (2014) 1-11.

[32] K.E.A. Ohlsson, T. Olofsson, Quantitative infrared thermography imaging of the density of heat flow rate through a building element surface, Appl. Energy 134 (2014) 499-505.

[33] G.I. Sultan, Enhancing forced convection heat transfer from multiple protruding heat sources simulating electronic components in a horizontal channel by passive cooling, Microelectronics J. 31 (2000) 773-779.

[34] M.M. Mohamed, Air cooling characteristics of a uniform square modules array for electronic device heat sink, Appl. Therm. Eng. 26 (2006) 486-493.

[35] G.S. Larraona, A. Rivas, R. Antón, J.C Ramos, I. Pastor, B. Moshfegh, Computational parametric study of an impinging jet in a cross-flow configuration for electronics cooling applications, Appl. Therm. Eng. 52 (2013) $428-438$.

[36] B.H. Chang, A.F. Mills, Effect of aspect ratio on forced convection heat transfer from cylinders, Int. J. Heat and Mass Transf. 47 (2004) 1289-1296.

[37] B. Melissari, S.A. Argyropoulos, Development of a heat transfer dimensionless correlation for spheres immersed in a wide range of Prandtl number fluids, Int. J. Heat and Mass Transf. 48 (2005) 4333-4341.

[38] M. García-Villalba, G. Palau-Salvador, W. Rodi, Forced convection heat transfer from a finite-height cylinder, Flow, Turbulence and Combust. 93 (2014) 171-187.

[39] T.T. Wong, C.W. Leung, Z.Y. Li, W.Q. Tao, Turbulent convection of air-cooled rectangular duct with surface-mounted cross-ribs, Int. J. Heat and Mass Transf. 
46 (2003) 4629-4638.

[40] B. Lu, P.-X. Jiang, Experimental and numerical investigation of convection heat transfer in a rectangular channel with angled ribs, Exp. Therm. and Fluid Sci. 30 (2006) 513-521.

[41] N. Onur, K. Arslan, Experimental investigation of laminar heat transfer inside trapezoidal duct having different corner angles, Exp. Heat Transf. 28 (2015) 89-105.

[42] H. Togoun, T. Abdulrazzaq, S.N. Kazi, A. Badarudin, A.A.H. Khadhum, E. Sadeghinezhad, A review of studies on forced, natural and mixed heat transfer to fluid and nanofluid in an annular passage, Renew. and Sustainable Energy Rev. 39 (2014) 835-856.

[43] J. Barranco, F. Barreras, A. Lozano, A.M. Lopez, V. Roda, J. Martin, M Maza, G.G. Fuentes, E. Almandoz, $\mathrm{Cr}$ and $\mathrm{Zr} / \mathrm{Cr}$ Nitride CAE-PVD Coated Aluminum Bipolar Plates for Polymer Electrolyte Membrane Fuel Cells, Int. J. Hydrogen Energy 35 (2010) 11489-11498.

[44] J. Barranco, F. Barreras, A. Lozano, M. Maza, Influence of CrN-coating thickness on the corrosion resistance behaviour of aluminium-based bipolar plates, J. Power Sources 196 (2011) 4283-4289.

[45] F. Barreras, A. Lozano, V. Roda, J. Barroso, J. Martín, Optimal design and operational tests of a high-temperature PEM fuel cell for a combined heat and power unit, Int. J. Hydrogen Energy 39 (2014) 5388-5398.

[46] F. Barbir, Fuel Cells. Theory and Practice, first edition, Elsevier Academic Press, USA, 2005.

[47] J.P. Holman, Heat Transfer, tenth edition, McGraw-Hill Higher Education - USA, 2010.

[48] S.A. Klein, Engineering Equation Solver (EES) for Microsoft Windows operating software. Commercial and professional versions, F Chart Software, 2014.

[49] J. Kiefer, Sequential minimax search for a maximum, Proc. Am. Math. Soc. 4 (1953) 502-506.

[50] D.F. Barbin, L.C. Neves Filho, V. Silveira Júnior, Convective heat transfer coefficients evaluation for a portable forced air tunnel, Appl. Therm. Eng. 30 (2010) 229-233 
[51] Y.A. Cengel, A.J. Ghaja, Heat and Mass Transfer: Fundamentals and Applications. Fifth Edition in SI Units, McGraw-Hill Education - Asia, 2015.

[52] D.G. Hyams, CurveExpert Professional Version 2.2.0. A comprehensive data analysis system for Windows, Mac, and Linux, 2014.

[53] V. Gnielinski, New equations for heat and mass transfer in turbulent pipe and channel flow, Int. Chem. Eng. 16 (1976) 359-368.

[54] H. Hausen, Darstellung des Wärmeübergangs in Rohren durch verallgemeinerte Potenz beziehungen, VDIZ 4 (1943) 91.

[55] C.Y. Chen, G.A. Hawkins, H.L Solberg, Heat transfer in annuli, Trans. Am. Soc. Mech. Eng. 68 (1946) 99-105.

[56] Standard Atmosphere, ISO 2533:1975, Geneva, Switzerland, 1975.

[57] A.M. López-Sabirón, J. Barroso, V. Roda, J. Barranco, A. Lozano, F. Barreras, Design and development of the cooling system of a $2 \mathrm{~kW}$ nominal power opencathode of a polymer electrolyte fuel cell stack, Int. J. Hydrogen Energy 37 (2012) 7289-7298.

[58] F. Barreras, A. Lozano, J. Barroso, V. Roda, M. Maza, Theoretical model for the optimal design of air cooling systems of polymer electrolyte fuel cells. Application to a high-temperature PEMFC, Fuel Cells 13 (2013) 227-237.

[59] Compact axial fan catalogue of the ebm-papst St. Georgen GmbH \& Co. KG, in http://www.ebmpapst.com/de. 